\title{
Early Diagenesis Records and Pore Water Composition of Methane-Seep Sediments from the Southeast Hainan Basin, South China Sea
}

\author{
Daidai Wu, ${ }^{1,2}$ Nengyou Wu, ${ }^{1,2}$ Ying Ye, ${ }^{3}$ Mei Zhang, ${ }^{1,2}$ Lihua Liu, ${ }^{1,2}$ \\ Hongxiang Guan, ${ }^{1,2}$ and Xiaorong Cong, 2 \\ ${ }^{1}$ Key Laboratory of Renewable Energy and Gas Hydrate, Guangzhou Institute of Energy Conversion, CAS, Guangzhou 510640, China \\ ${ }^{2}$ Guangzhou Center for Gas Hydrate Research, CAS, Guangzhou 510640, China \\ ${ }^{3}$ Department of Ocean Science and Engineering, Zhejiang University, Hangzhou 310028, China
}

Correspondence should be addressed to Nengyou Wu, wuny@ms.giec.ac.cn

Received 14 April 2011; Revised 4 August 2011; Accepted 4 August 2011

Academic Editor: Umberta Tinivella

Copyright (C) 2011 Daidai Wu et al. This is an open access article distributed under the Creative Commons Attribution License, which permits unrestricted use, distribution, and reproduction in any medium, provided the original work is properly cited.

\begin{abstract}
Several authigenic minerals were identified by XRD and SEM analyses in shallow sediments from the Southeast Hainan Basin, on the northern slope of South China Sea. These minerals include miscellaneous carbonates, sulphates, and framboidal pyrite, and this mineral assemblage indicates the existence of gas hydrates and a methane seep. The assemblage and fabric features of the minerals are similar to those identified in cold-seep sediments, which are thought to be related to microorganisms fostered by dissolved methane. Chemical composition of pore water shows that the concentrations of $\mathrm{SO}_{4}^{2-}, \mathrm{Ca}^{2+}, \mathrm{Mg}^{2+}$, and $\mathrm{Sr}^{2+}$ decrease clearly, and the ratios of $\mathrm{Mg}^{2+}$ to $\mathrm{Ca}^{2+}$ and $\mathrm{Sr}^{2+}$ to $\mathrm{Ca}^{2+}$ increase sharply with depth. These geochemical properties are similar to those where gas hydrates occur in the world. All results seem to indicate clearly the presence of gas hydrates or deep water oil (gas) reservoirs underneath the seafloor.
\end{abstract}

\section{Introduction}

Methane is a major component of cold fluids on the continental shelf and slope [1,2]. It is also a major hydrocarbon gas source of deep oilgas and gas hydrates. Hydrocarbon gas can escape through the overlying marine sediment column, enter the water column, and form a coldseep $[1,3,4]$. Most of the hydrocarbon gas can generate authigenic carbonates at or under the seafloor via a series of biogeochemical reactions, and a small amount may even be transported into the water column or enter the atmosphere $[5,6]$. Hydrocarbon gas seep provides nourishment for Archaea and sulfate- reducing bacteria (SRB) found in benthic sediments. These microorganisms consume sulfate and oxydize methane into $\mathrm{HCO}_{3}{ }^{-}$. This process causes changes of pore water chemical composition and results in the precipitation of carbonate $[7,8]$. Methane seeps are an important geological phenomenon in marine sediment, and methane-rich cold seeps are assumed to be the preferential outcrop of oilgas and gas hydrate on the seafloor. Therefore, the knowledge of methane seeps is significant for oil-gas exploration. Furthermore, the greenhouse potential of methane is 24 times of carbon dioxide. Compared to the artificial carbon dioxide, the greenhouse effect of methane discharged by geodynamic and tectonic processes plays a primary role on the global change in the natural environment [9]. Therefore, there has been an increasing interest in methane seepage (gas hydrate) during the past several years.

Southeast Hainan Basin on the northern slope of South China Sea is a potential gas hydrate deposit. Except for direct drilling and sampling of marine gas hydrates, the occurrence of gas hydrates has been identified generally by inference from indirect evidence, derived from geological, geophysical, and geochemical data all over the world. For example, the occurrence of gas hydrate is inferred from seismic profiles, especially the bottom simulating reflector (BSR), although 
gas hydrates are also known to occur in the areas without BSR in many locations. In Southeast Hainan Basin, the highresolution multichannel seismic profiles were collected, and BSR and other seismic indications, such as blanking zone and velocity amplitude anomaly inversions, for gas hydrate occurrences, were observed. However, geochemical studies have been of great help for identification of the occurrence of gas hydrates.

The goal of this research is to study the early diagenesis records and geochemistry of pore waters of shallow sediments from Southeast Hainan Basin. The evidences for gas hydrates or deep water oil (gas) reservoirs and the relationship between authigenic mineral, geochemistry of pore waters, and methane seep in shallow sediments were discussed here.

\section{Geological Setting and Sampling}

A $4.9 \mathrm{~m}$ long sediment core was taken in August 2005 from $1508 \mathrm{~m}$ depth in the Southeast Basin (Figure 1) by a gravity piston corer, during the HY4-2005-5 Cruise of R/V Haiyang4 (Guangzhou Marine Geological Survey, Ministry of Land and Natural Resources). The cored sediment is silty clay with a few foraminifera, yielding strong odor of hydrogen sulfide. The sediment core was stored on board at $4^{\circ} \mathrm{C}$. The sampling site $\mathrm{T} 1\left(111^{\circ} 4^{\prime} \mathrm{E}, 18^{\circ} 2^{\prime} \mathrm{N}\right)$ is located in a flat continental slope, $150 \mathrm{~km}$ southeast of Sanya, Hainan Province, China. The geological structural unit belongs to the Songxi Depression Belt, Southeast Hainan Basin.

Oil- and gas-bearing depositional basins on the northern continental slope of the South China Sea were developed during the late Cenozoic [10-12], when a strong extrusion phase followed a period of rift extension and sea-floor spreading 30 24 Ma ago. The area (Figure 1) is characterized by frequent tectonic and magmatic episodes, slope slumps, high heat flux (average about $75 \mathrm{~mW} / \mathrm{m}^{2}$ ), abundant thermogenic gas and biogas in shallow sediments, carbon dioxide and nitrogen-rich gas. Four subareas, including Southwest Taiwan, Northeast Dongsha, Baiyun Sag of Pearl River Mouth Basin, and Southeast Hainan Basin, were identified to be the most favorable for gas seep or gas hydrate presence, showing geological, geochemical, and biological evidences for cold seeps [13-21]. The sediment thickness is reported to be about $12000 \mathrm{~m}$ [22], whereas $5000 \mathrm{~m}$ thick organic-rich sediments have been accumulated since the Cenozoic [23].

The thick Quaternary organic-rich sediments in Southeast Hainan Basin provide enough sources for hydrocarbons [24]. High geothermal gradient [25] and abnormal high pressure [26] are fitted for hydrocarbons formation, diffusion, and transportation. Methane-rich gas is categorized into three groups: bio-low mature transient gas, normal mature thermogenic gas, and super mature thermogenic gas [23], and the conditions for gas hydrate accumulation were confirmed in previous studies [27]. Some methaneseep-related features, such as mud volcanoes, mud diapirs, and gas chimneys, were discovered in the basin [24, 28]. Unfortunately, there is no similar report at the sampling site, even if the existence of gas hydrates in the Southeast Hainan
Basin has been confirmed by geophysical evidences [24, 2830]. The existence of gas hydrate in the same site (T1) has also been proved by microbial evidence [31].

\section{Materials and Methods}

The sediment cores within PVC liners were immediately cut into $80 \mathrm{~cm}$ sections after its recovery on deck. The core sections were airtight sealed with plastic cap, gummed typed and stored on board at $4^{\circ} \mathrm{C}$. The sealed sections were further splitted longitudinally in a flow-through $\left(\mathrm{N}_{2}\right)$ anaerobic chamber at Guangzhou Marine Geological Survey, China. One half of each section was described and archived, while the other half was sampled for pore water and sediment. The external rim of each subsection was removed using sterile tools to avoid contamination. Subsections of freshly cored sediments were removed and placed into special sealed glass bottles. The samples were stored at $4^{\circ} \mathrm{C}$ for X-ray diffraction (XRD), scanning electron microscope (SEM), and pore water analysis. All analyses were carried out at the Department of Geological Sciences and the Department of Biology, University of Miami.

XRD was employed to analyze mineralogy in the sediments. Samples were oven heated at $60^{\circ} \mathrm{C}$ for $12 \mathrm{hrs}$, pestled into less than $200 \mu$ mesh, and X-rayed with a Scintag XGEN-4000 X-ray diffraction system, using $\mathrm{Cu}$ radiation in a graphite monochromator, a scintillation counter, with 0.02 two-theta steps from 5 to 70 degrees, for 2 seconds per step, with $0.15406 \mathrm{~nm}$ wavelength, $40 \mathrm{kV}$ tube voltage, and $34 \mathrm{~mA}$ tube current. Mineral identification was done by a combination of search-match software and comparison with the JCPDS card files.

A Zeiss Supra 35 VP-FEG SEM equipped with EDAX Energy Dispersive X-ray microanalysis system was used to identify minerals and to image their morphologies. In preparation for SEM observations, selected samples were vacuum dried and gold coated. The working distance is $10.3 \mathrm{~mm}$, and voltage is $5 \mathrm{kV}$.

Sediment pore water samples were collected after centrifugation of about $50 \mathrm{~g}$ sediment subsamples (5000 g for 10 minutes). Each sediment subsample could obtain about 13-20 mL water. To measure anions and cations, aliquots of pore water were mixed with $0.1 \mathrm{HCl}$ solutions. The diluted (pore water samples) solutions were then analyzed by highperformance liquid chromatography (HPLC) for anions (IonPacAS14 column $4 \times 250 \mathrm{~mm}$ ) and direct current plasma emission spectrometry (DCP) for cations.

\section{Results and Discussions}

4.1. Authigenic Minerals and Microstructures of Sediments. XRD results (Figure 2) show that the sediments contain land-derived detrital minerals, that is, quartz, illite, kaolinite, albite, calcite, and a complex suite of authigenic minerals, that is, miscellaneous carbonates, sulphates, and pyrite. Major mineral components and their semiquantification are listed in Table 1. Abundant microstructures were observed by SEM (Figure 3), and the whole crystal form, surface, 


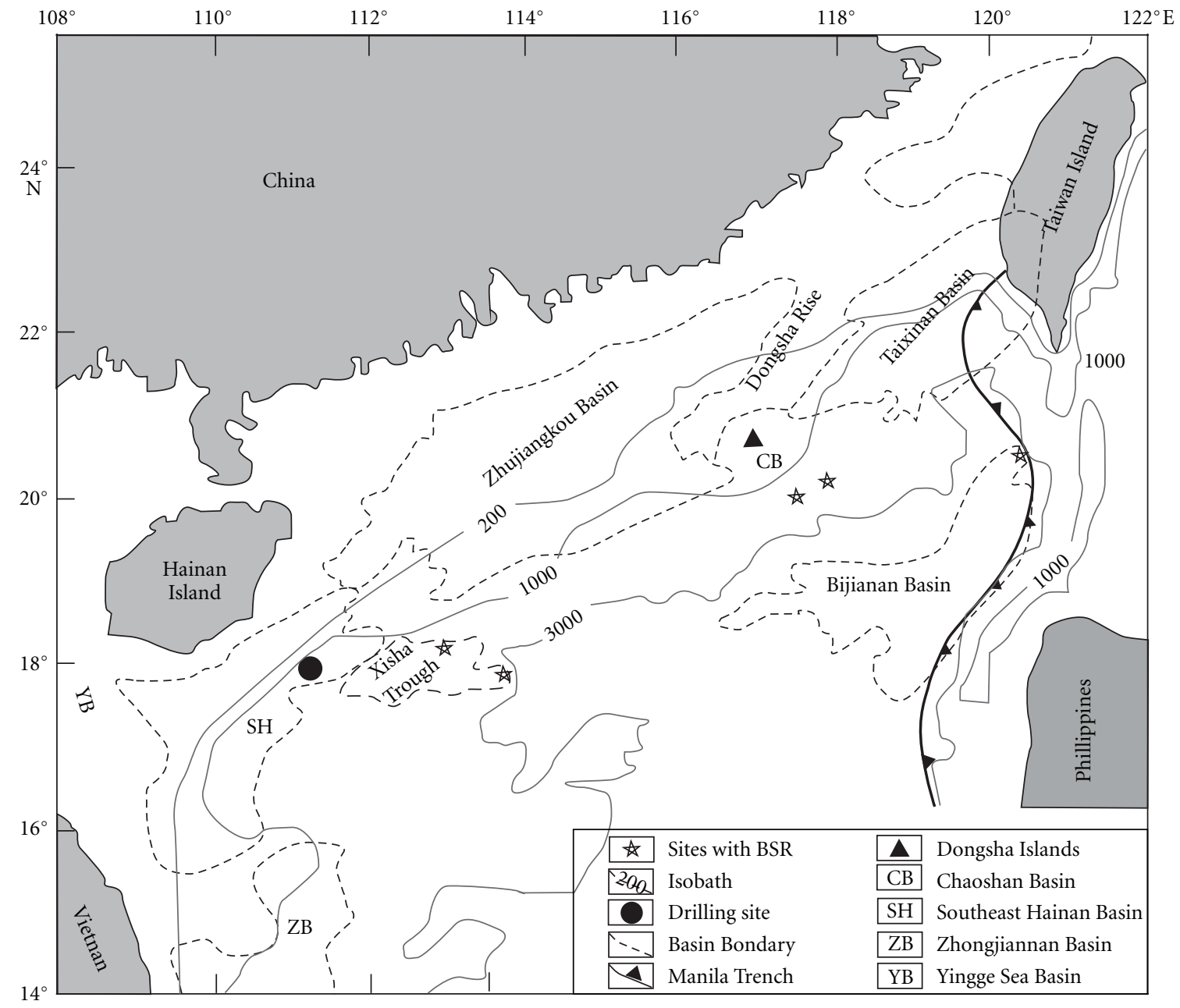

Figure 1: Position of the sampling site, Southeast Hainan Sea, South China Sea.

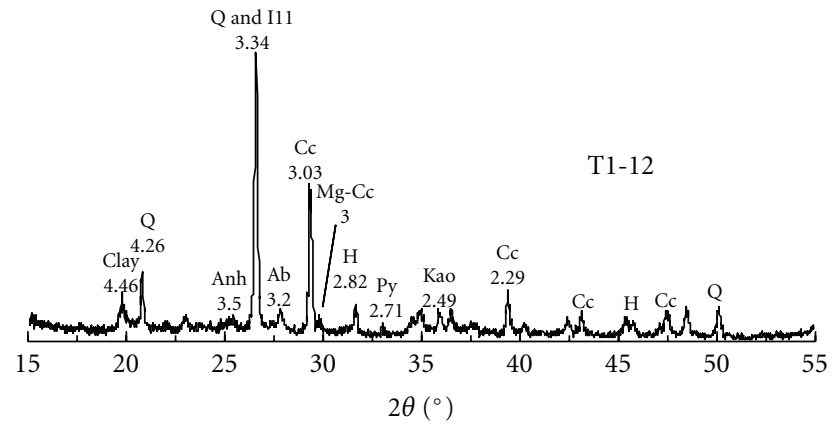

Figure 2: XRD pattern of mineral components in sample T1-12 from the Southeast Hainan Basin. Clay, clay minerals; Q, quartz; Anh, anhydrite; Ill, illite; $\mathrm{Ab}$, albite; $\mathrm{Cc}$, calcite; $\mathrm{Mg}$-Cc, $\mathrm{Mg}$-calcite; $\mathrm{H}$, halite; Py, pyrite; Kao, kaolinite.

angle, and crystallographic elements are kept intact during the observations. These characters confirm that the minerals are authigenic in situ, without transport and erosion.

Main identified miscellaneous carbonates are calcite, Mg-calcite, nesquehonite, magnesite, siderite, and so forth.
Calcite is one of the major components in the sediment samples, and most part of it is foraminifera shell. Mgcalcite and nesquehonite are common in XRD patterns, but magnesite and siderite are only identified in few subsamples. Part of calcite is aragonite pseudomorph, which looks like an assemblage with acicular, filiform, and ball-shaped carbonates under SEM. The assemblage is identified with calcite by energy dispersive X-ray spectra. However, the crystal form and habit are similar to aragonite (Figures 3(c), 3(d)). There is no identified aragonite peaks in the XRD pattern, which suggests that aragonite was replaced by calcite, and the pseudomorph of aragonite is observed. It evinces that phase transformation of aragonite into calcite has occurred in sediments. The factor leading to formation of acicular, filiform, and ball-shaped aragonite is metabolism of methane-related microorganisms. Sassen et al. found that acicular aragonite, framboidal pyrites, mycelium, and asphalt have symbiotic relationship in cold seep carbonates [5], and the bacterium activity boosting precipitation of authigenic carbonates has been discovered by lab work [32, 33]. Ehrlich observed successfully ball-shaped and dumbbell assemblage of acicular aragonite by bacilli culture in laboratory [34]. Ball-shaped 


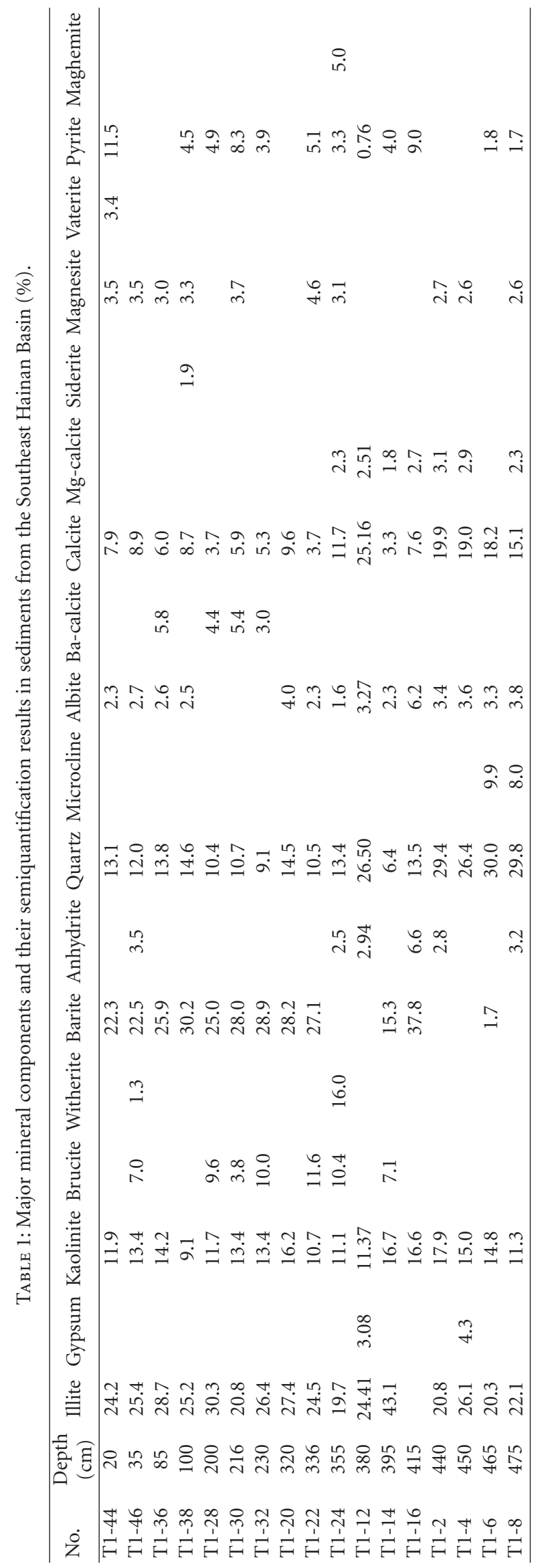




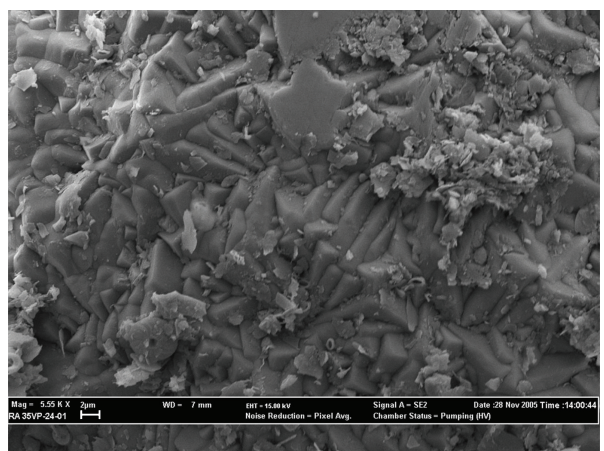

(a) Authigenic carbonates, T1-4

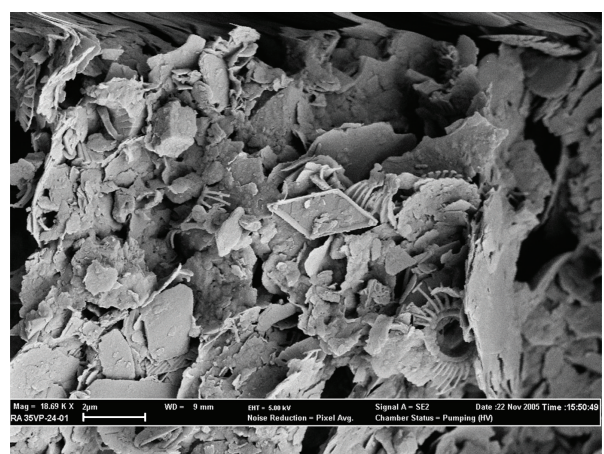

(b) Authigenic dolomite (euhedral rhombus crystal), T1-38

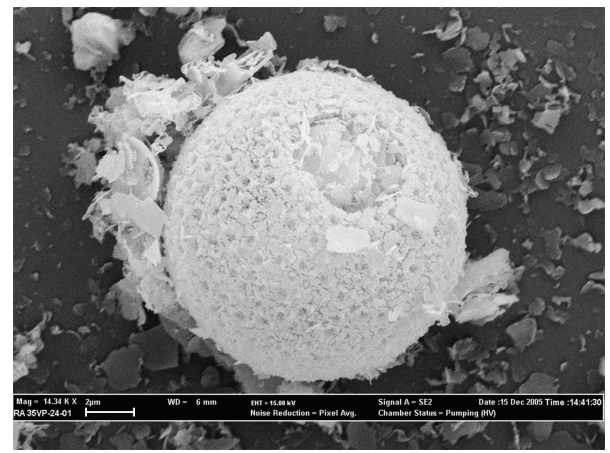

(d) Ball-shaped aragonite assemblage, T1-22

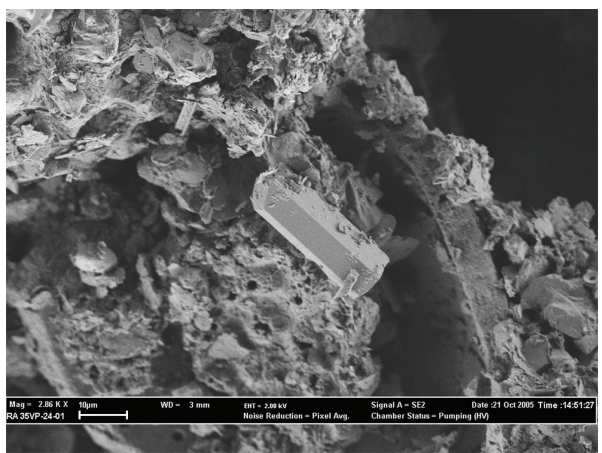

(f) Authigenic Barite, T1-20

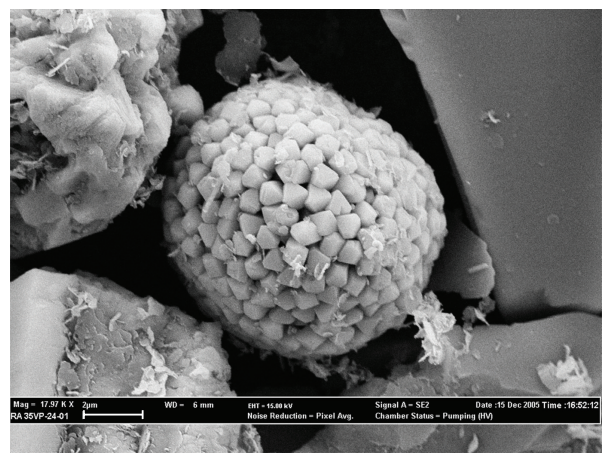

(h) Authigeni framibiodal pyrite, T-16

(g) Authigenic pyrite, T1-28

FIGURE 3: SEM images of authigenic minerals in sediments from the Southeast Hainan Basin. 
carbonates cemented by mycelium were observed under SEM (Figure 3(d)), which further confirmed that there was some cause-effect relationship between carbonates assemblage and microorganism. Mg-calcite and Nesquehonite are authigenic rhombohedral crystals, and usually coat the surface of microorganism shells like coccoliths, diatoms, and so on [5].

Authigenic carbonates deposits have been documented in area near methane seep in both the active and passive continental margin $[5,6]$. The carbonates formation relates closely to methane seep or gas hydrate decomposition because of their special microstructure $[2,35]$. The Southeast Hainan Basin in South China Sea is a potential area for gas hydrate reservoirs. Methane microseep and its oxidation drive the bicarbonate deposited associating with the available research data although there are no large methane seep found at the sampling site.

Main sulphate minerals identified in the sediments are barite, anhydrate, and gypsum. Gypsum and anhydrite appear as tabular and panidiomorphic textures (Figure 3(e)). The occurrence of authigenic gypsum and anhydrite indicates high concentration of sulphate ion in the pore water. Sulfate reduction is the main pathway of $\mathrm{CH}_{4}$ oxidation in $\mathrm{CH}_{4}$-riched anoxic sediments. Although the $\mathrm{CH}_{4}-\mathrm{SO}_{4}{ }^{2-}$ redox cell will decompose and consume sulphate in the sediments, that does not mean there is no $\mathrm{SO}_{4}{ }^{2-}$. On the contrary, $\mathrm{SO}_{4}{ }^{2-}$ originates from the decomposition of organic-rich sediments, and there must be abundant organic matter in gas hydrate reservoirs [36], whereas $\mathrm{Ca}^{2+}$ may originate from the decomposition of calcilith or fluids with $\mathrm{Ca}^{2+}$ from the gas hydrate present underneath [37]. Therefore, the supersaturated concentration of $\mathrm{Ca}^{2+}$, and $\mathrm{SO}_{4}{ }^{2-}$ in pore water drives authigenic gypsum precipitation. Authigenic gypsum has been identified in the sediments from Hydrate Ridge in the northeast Pacific Ocean. That indicates gypsum should be one of the authigenic minerals which have close relation with methane hydrate reservoir [38]. In conclusion, gypsum is one of the markers for hydrate presence similar to other authigenic minerals, carbonates, and barite.

Barite shows a short prismatic and euhedral crystal structure under SEM (Figure 3(f)). Authigenic barite micro-crystals had been indentified in sediments from the Peru continental margin (site 684) and Japan Sea (site 799) by the Ocean Drilling Program (ODP), and they contain more ${ }^{34} \mathrm{~S}$ than that in the sea water with a $\delta^{34} \mathrm{~S}$ of $+84 \%$. The widespread occurrence of barite indicates high concentration of $\mathrm{Ba}$ in pore water. Barite is the major mineral in the coldseep sediments in Peru and Russian Okhotsk [39, 40]. The source of $\mathrm{Ba}$ in the cold seep is assumed to be the barite solution as a result of the sulphate deoxidization at depth [41].

Pyrite was identified in most samples by XRD analysis, and the representative diffraction peaks are $2.709 \times 10^{-10}$ and $2.423 \times 10^{-10} \mathrm{~m}$. Pyrite is distributed as single granules (Figure $3(\mathrm{~g})$ ) or framboidal assemblages (Figure $3(\mathrm{~h})$ ); $\delta^{34} \mathrm{~S}$ value of the framboidal pyrite is greatly negative in coldseep sediments and low-temperature hydrothermal fluid sediments. This indicates that the sulphur of pyrite originates from bacterial reduction of sulphate in sea water [42-44].
Sulphate bacteria mainly depend on sulphate decomposition in the anoxic environment by activity of sulphate redox cell. Meanwhile, the $\mathrm{HCO}_{3}{ }^{-}$concentration increases in the pore water with decomposition of organic matter. Sulphide forms with free $\mathrm{HS}^{-}$and low-valence iron, and finally sulphide transforms into pyrite $[45,46]$. Sassen et al. found many framboidal pyrites, and pyrite granules in sediments from a gas hydrate area in the Golf of Mexico and suggested that the strong anaerobic methane oxidation (AOM) contributes to pyrite formation in sediments [5]. Liu et al. also believed that AOM is the main reason for sulphide increase in the sediments from the northeastern South China Sea [47]. Therefore, authigenic pyrite is also the major product of AOM process in sediments from a gas hydrate (methane seep) area. High concentration of pyrite in anoxic sediments can indicate the methane abnormality [48] and the occurrence of methane-rich fluids and further show the shallow SMI to a certain degree.

In summary, AOM in the methane seep area results in alkalinity increase in both pore water and sea water $[49,50]$. Methane is oxidized to $\mathrm{HCO}_{3}{ }^{-}$by $\mathrm{SO}_{4}{ }^{2-}$, a process in favor of $\mathrm{CO}_{3}{ }^{2-}$ accumulation. Furthermore, $\mathrm{AOM}$ changes the geochemical conditions and results in the rapid deposition of miscellaneous carbonates including aragonite, $\mathrm{Mg}$-calcite, and dolomite [51]. Meanwhile, pyrite formation results from the reaction of $\mathrm{H}_{2} \mathrm{~S}$, derived from bacterial sulphate reduction, with reactive iron $[45,46]$. Precipitation of aragonite, $\mathrm{Mg}$-calcite, and pyrite is the result of processes related to the presence of methane seep in the northern Black sea $[1,8]$. Abundant cold-seep-related minerals, Mgcalcite, dolomite, and framboidal pyrite, precipitate in Monterey Gulf, California [52]. Authigenic minerals including miscellaneous carbonates, sulphate, and sulphide form in gas hydrate-bearing and hydrocarbon seepage in Gulf of Mexico [5]. All these records of authigenic mineral assemblages and fabric features are geological evidences for cool-seep activities, hydrocarbon seeps, and gas hydrate dissociation. The widespread occurrence of authigenic carbonates, pyrite, and sulphate in the sediments of Southeast Hainan Basin, South China Sea is completely similar to reported cases in a typical gas hydrate area. This aspect further indicates gas hydrate existence in the study area.

4.2. Chemical Composition of Pore Waters. Anomalies in the chemical composition of pore water indicating the occurrence of gas hydrates, such as anomalous concentrations of $\mathrm{Br}, \mathrm{Cl}, \mathrm{CH}_{4}$, and $\mathrm{K}$, are known in the literature $[53,54]$.

In pore waters from the Southeast Hainan Basin, $\mathrm{NH}_{4}{ }^{+}$ concentration is close to zero within the upper $320 \mathrm{~cm}$ section and increases with depth in lower section (Table 2, Figure 4). That may be due to the zymosis of organic matter via bacteria during gas hydrate formation and dissociation [55]. The concentration of $\mathrm{Mg}^{2+}$ decreases slightly with depth, and the $\mathrm{Ca}^{2+}$ concentration falls slightly (Table 2, Figure 4). The solubility product of calcium carbonate is less than magnesium, and calcium carbonate deposits easily from the solution. Therefore, $\mathrm{Ca}^{2+}$ deposits faster than $\mathrm{Mg}^{2+}$ from 
TABLE 2: Pore water chemical composition for the analysed core from the Southeast Hainan Basin (mg/dm³).

\begin{tabular}{lccccccrrr}
\hline Depth $(\mathrm{cm})$ & $\mathrm{NH}_{4}^{+}$ & $\mathrm{K}^{+}$ & $\mathrm{Mg}^{2+}$ & $\mathrm{Ca}^{2+}$ & $\mathrm{Mn}^{2+}$ & $\mathrm{Fe}^{2+}$ & $\mathrm{F}^{-}$ & $\mathrm{Br}^{-}$ & $\mathrm{SO}_{4}^{2-}$ \\
\hline 20 & 0.0 & 585.1 & 1465.9 & 510.1 & 17.7 & 28.8 & 3.0 & 71.4 & 2559.5 \\
35 & 0.0 & 561.4 & 1421.1 & 529.1 & 17.2 & 19.9 & 2.7 & 69.3 & 2496.8 \\
85 & 0.0 & 588.1 & 1448.6 & 487.3 & 16.8 & 45.6 & 3.0 & 70.8 & 2447.2 \\
100 & 0.0 & 571.2 & 1393.3 & 466.7 & 15.8 & 36.6 & 4.4 & 69.7 & 2308.3 \\
200 & 0.0 & 592.1 & 1446.4 & 469.2 & 9.0 & 35.7 & 4.2 & 79.1 & 2423.1 \\
216 & 0.0 & 558.9 & 1342.0 & 429.9 & 8.5 & 30.5 & 3.2 & 65.3 & 2199.2 \\
230 & 0.0 & 592.8 & 1412.7 & 461.5 & 8.8 & 48.7 & 3.0 & 68.1 & 2323.2 \\
320 & 0.0 & 674.6 & 1521.3 & 431.2 & 7.5 & 18.1 & 4.1 & 71.5 \\
336 & 10.7 & 558.5 & 1412.9 & 439.9 & 8.0 & 27.0 & 3.5 & 75.4 & 2014.3 \\
355 & 0.0 & 565.9 & 1460.6 & 466.5 & 8.8 & 46.9 & 3.1 & 78.5 & 2175.8 \\
380 & 26.4 & 552.7 & 1424.1 & 429.8 & 7.8 & 18.0 & 3.0 & 67.8 & 2170.3 \\
395 & 22.8 & 595.4 & 1415.8 & 423.2 & 7.9 & 28.6 & 3.2 & 76.0 \\
415 & 15.7 & 546.4 & 1406.7 & 439.1 & 8.9 & 53.2 & 3.7 & 71.8 & 2173.7 \\
440 & 44.7 & 537.8 & 1375.7 & 412.3 & 12.0 & 22.2 & 3.0 & 72.7 & 2074.6 \\
450 & 55.5 & 579.6 & 1421.8 & 412.7 & 7.6 & 9.0 & 3.8 & 77.6 \\
465 & 53.6 & 550.5 & 1434.4 & 425.2 & 8.0 & 14.4 & 4.7 & 79.2 & 2163.0 \\
475 & 61.3 & 595.2 & 1407.1 & 363.0 & 7.3 & 25.2 & 4.1 & 72.6 & 2078.0 \\
\hline
\end{tabular}
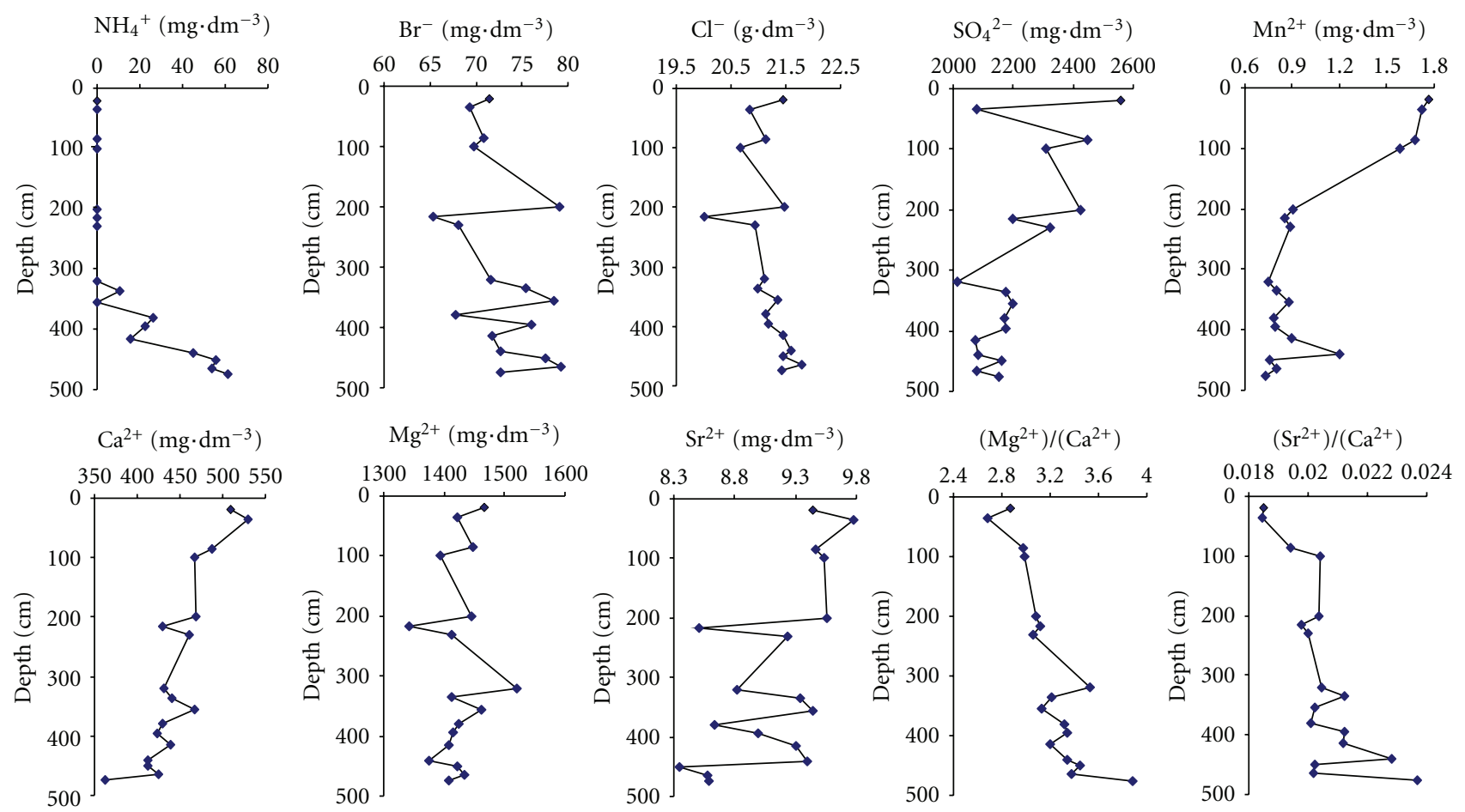

FIGURE 4: Geochemistry of pore waters versus depth of sediments from the Southeast Hainan Basin.

pore water into solid phase. Furthermore, the $\mathrm{Mg}^{2+} / \mathrm{Ca}^{2+}$ ratio increases sharply with depth (Figure 4). The concentrations of $\mathrm{Sr}^{2+}$, and $\mathrm{Mn}^{2+}$ go down sharply with depth in the shallow sediments (Table 2). This suggests that $\mathrm{Sr}^{2+}$ and $\mathrm{Mn}^{2+}$ are removed into the same authigenic phase(s). Also the ratio of $\mathrm{Sr}^{2+}$ to $\mathrm{Ca}^{2+}$ increases sharply with depth (Figure 4), and the cause may be that $\mathrm{Ca}^{2+}, \mathrm{Mg}^{2+}, \mathrm{Sr}^{2+}$, and $\mathrm{Mn}^{2+}$ cations are easily incorporated within carbonates deposited at the expense of dissolved carbon dioxide. The consumption of $\mathrm{Ca}^{2+}, \mathrm{Mg}^{2+}, \mathrm{Sr}^{2+}$, and $\mathrm{Mn}^{2+}$ cations in pore water, combined with the authigenic carbonates like calcite (aragonite pseudomorphous), Mg-calcite, and magnesite, indicates that there is supplement of dissolved $\mathrm{CO}_{2}$ likely originated from $\mathrm{AOM}$ in depth during the diagenesis process, then diagenesis is a process affecting $\mathrm{AOM}$ and providing cations and dissolved species to pore water for further 
reactions. Previous research showed that carbon dioxide could form during gas hydrate decomposition and upper migration in gas hydrate-bearing areas, leading to formation of authigenic carbonates, syngenetic to gas hydrate $[56,57]$.

The concentrations of $\mathrm{Cl}^{-}$and $\mathrm{Br}^{-}$are relatively constant, whereas $\mathrm{SO}_{4}{ }^{2-}$ decreases clearly with depth (Figure 4). These trends, combined with the presence of authigenic carbonates, barite, gypsum, anhydrite, and pyrite, indicate $\mathrm{AOM}$ and sulphate reduction

$$
\mathrm{CH}_{4}+\mathrm{SO}_{4}{ }^{2-} \longrightarrow \mathrm{HCO}_{3}{ }^{-}+\mathrm{HS}^{-}+\mathrm{H}_{2} \mathrm{O}
$$

The reaction has affected the shallow sediments at the site T1 of the Southeast Hainan Basin, South China Sea, or the sulphate-methane interface (SMI) has been lifted up to the shallow layer. It means that there is abundance of gas hydrate or gas-oil resource underneath the sampling site. Compared to other methane seep area, the concentration gradient of sulphate in core T1 is smaller. That means sulfate in pore water is not exhausted in sampling depth. So, the depth of SMI should be deeper than the sampling's. Therefore, it is clear that there is a hypogenetic fluid, related to gas hydrate occurrence under the sampling site.

The results of microbial colony research at same site [31] demonstrated that physiological functions of these relatives include $\mathrm{Fe}(\mathrm{III})$ and $\mathrm{Mn}(\mathrm{IV})$ reduction (Pelobacter), sulfate reduction $\left(\mathrm{H}_{2} \mathrm{~S}\right.$ production) (S. kaireitica), decomposition of complex aromatic hydrocarbons and denitrification $(P$. stutzeri), hydrocarbon degradation (A. jadensis), and thiosulfate/sulfite oxidation (Sulfitobacter spp.) in the sediments, similarly to observations of gas hydrate-bearing sediments in the Sea of Okhotsk [58]. The occurrence of microbe suggests hydrocarbon oxidation coupled with sulphate, and Fe (III) reduction is an important process during the early diagenesis in the Southeast Hainan Basin, South China Sea. Oxidation of hydrocarbons may contribute to the increasing alkalinity and carbonate precipitation. The metabolic processes are consistent with the decreasing $\mathrm{Mg}^{2+}, \mathrm{Ca}^{2+}, \mathrm{Sr}^{2+}$ and $\mathrm{SO}_{4}{ }^{2-}$ concentrations in pore water, the precipitation of authigenic carbonates and pyrite in the shallow sediments. These results strongly suggest that there should be gas hydrae reservoirs in the sampling area.

\section{Conclusions}

Taking together all available mineralogical and geochemical data from the Southeast Hainan Basin, South China Sea, we can draw the following conclusions.

(1) The shallow sediments from the Southeast Hainan Basin are of a complex suite of authigenic minerals, such as carbonates, sulphates, and framboidal pyrite, indicating clearly the existence of gas hydrates or deep water oil (gas) reservoirs. The assemblage and fabric features of aragonite and mg-calcite could be a result of the activity of microorganisms, which consumes dissolved methane. The miscellaneous authigenic carbonates are the result of abundant $\mathrm{HCO}_{3}{ }^{-}$in the pore water, whose source should be related to AOM by microorganisms. Reduction of sulphate and iron may be coupled with oxidation of methane and hydrocarbons, which causes decreased $\mathrm{SO}_{4}{ }^{2-}$ concentration in pore water and precipitation of authigenic pyrite and carbonates in the sediments.

(2) Chemical composition of pore waters shows that the concentrations of $\mathrm{SO}_{4}{ }^{2-}, \mathrm{Mg}^{2+}, \mathrm{Ca}^{2+}, \mathrm{Sr}^{2+}$ and $\mathrm{Mn}^{2+}$ decrease, and the concentration of $\mathrm{NH}_{4}{ }^{+}$increases with depth. The ratios of $\mathrm{Mg}^{2+} / \mathrm{Ca}^{2+}, \mathrm{Sr}^{2+} / \mathrm{Ca}^{2+}$ increase sharply with depth. These geochemical data indicate strongly the presence of gas hydrates or deep water oil (gas) reservoirs beneath the seafloor.

In summary, mineralogical and geochemical data in the shallow sediments and pore waters suggest to us that the Southeast Hainan Basin is one of the promising targets on the northern margin of the South China Sea for further gas hydrate or deep water oil (gas) reservoir exploration. The data allow us to better understand the influence on the methane seep and geochemistry of fluids in shallow sediments exerted by gas hydrates or deep water oil (gas) reservoirs, whose presence could not be determined with certainty until there is further evidence, and the presence of methane seeps on the seafloor needs to be evidenced by swath bathymetry, shallow seismic data, or direct evidence on seafloor images in the future.

\section{Acknowledgments}

This study is financially supported by the National Natural Science Foundation of China (No. 41003010 and No.U0933004), National 973 Project (No. 2009CB219506), and Scientific and Technology Program of Guangdong Province (No. 2011A080403021). We sincerely thank the crew and scientific team onboard R/V Haiyang-4 from Guangzhou Marine Geological Survey for their cooperation and highly professional support, two anonymous reviewers for their kind comments and suggestions.

\section{References}

[1] J. Peckmann, A. Reimer, U. Luth et al., "Methane-derived carbonates and authigenic pyrite from the northwestern Black Sea," Marine Geology, vol. 177, no. 1-2, pp. 129-150, 2001.

[2] C. Pierre and J. M. Rouchy, "Isotopic compositions of diagenetic dolomites in the Tortonian marls of the western Mediterranean margins: evidence of past gas hydrate formation and dissociation," Chemical Geology, vol. 205, no. 3-4, pp. 469484, 2004.

[3] J. Peckmann and V. Thiel, "Carbon cycling at ancient methane-seeps,” Chemical Geology, vol. 205, no. 3-4, pp. 443-467, 2004.

[4] D. Wu, N. Wu, Y. Ye, P. Zhang, and X. Chen, "Geochemical characteristics of hydrocarbon compounds in sediments of the eastern South China Sea," Acta Petrolei Sinica, vol. 29, no. 4, pp. 516-521, 526, 2008 (Chinese).

[5] R. Sassen, H. H. Roberts, R. Carney et al., "Free hydrocarbon gas, gas hydrate, and authigenic minerals in chemosynthetic communities of the northern Gulf of Mexico continental slope: relation to microbial processes," Chemical Geology, vol. 205, no. 3-4, pp. 195-217, 2004. 
[6] B. M. A. Teichert, G. Bohrmann, and E. Suess, "Chemoherms on Hydrate Ridge-unique microbially-mediated carbonate build-ups growing into the water column," Palaeogeography, Palaeoclimatology, Palaeoecology, vol. 227, no. 1-3, pp. 67-85, 2005.

[7] C. L. Zhang and B. Lanoil, "Geological and biogeochemical dynamics of gas hydrate-hydrocarbon seep systems," Chemical Geology, vol. 205, pp. 187-194, 2004.

[8] J. Reitner, J. Peckmann, M. Blumenberg, W. Michaelis, A. Reimer, and V. Thiel, "Concretionary methane-seep carbonates and associated microbial communities in Black Sea sediments," Palaeogeography, Palaeoclimatology, Palaeoecology, vol. 227, no. 1-3, pp. 18-30, 2005.

[9] G. Etiope, "New directions: GEM-geologic emissions of methane, the missing source in the atmospheric methane budget," Atmospheric Environment, vol. 38, no. 19, pp. 30993100, 2004.

[10] S. L. McDonnell and M. Czarnecki, "A note on gas hydrate in the northern sector of the South China Sea," in Natural Gas Hydrate: In Oceanic and Permafrost Environments, M. D. Max, Ed., pp. 239-244, Kluwer Academic Publishers, Dodrecht, The Netherlands, 2000.

[11] T. M. Guo, B. H. Wu, Y. H. Zhu, S. S. Fan, and G. J. Chen, "A review on the gas hydrate research in China," Journal of Petroleum Science and Engineering, vol. 41, no. 1-3, pp. 11-20, 2004.

[12] S. Wu, G. Zhang, Y. Huang, J. Liang, and H. K. Wong, "Gas hydrate occurrence on the continental slope of the northern South China Sea," Marine and Petroleum Geology, vol. 22, no. 3, pp. 403-412, 2005.

[13] D.-F. Chen, Y.-Y. Huang, D. Feng, Z. Su, and G.-Q. Chen, "Seep carbonate and preserved bacteria fossils in the northern of the South China Sea and their geological implications," Bulletin of Mineralogy Petrology and Geochemistry, vol. 24, no. 3, pp. 185-189, 2005 (Chinese).

[14] H. Lu, J. Liu, F. Chen et al., "Mineralogy and stable isotopic composition of authigenic carbonates in bottom sediments in the offshore area of southwest Taiwan, South China Sea: evidence for gas hydrate occurrence," Earth Science Frontiers, vol. 12, no. 3, pp. 268-276, 2005 (Chinese).

[15] Z. Chen, W. Yan, M. Chen et al., "Discovery of seep carbonate nodules as new evidence for gas venting on the northern continental slope of South China Sea," Chinese Science Bulletin, vol. 51, no. 10, pp. 1228-1237, 2006.

[16] D. F. Chen, Y. Y. Huang, X. L. Yuan, and L. M. Cathles, "Seep carbonates and preserved methane oxidizing archaea and sulfate reducing bacteria fossils suggest recent gas venting on the seafloor in the Northeastern South China Sea," Marine and Petroleum Geology, vol. 22, no. 5, pp. 613-621, 2005.

[17] S. Lin, W. C. Hsieh, Y. C. Lim, T. F. Yang, C. S. Liu, and Y. Wang, "Methane migration and its influence on sulfate reduction in the good weather ridge region, South China Sea continental margin sediments," Terrestrial, Atmospheric and Oceanic Sciences, vol. 17, no. 4, pp. 883-902, 2006.

[18] T. F. Yang, P. C. Chuang, S. Lin, J. C. Chen, Y. Wang, and S. $\mathrm{H}$. Chung, "Methane venting in gas hydrate potential area offshore of SW Taiwan: evidence of gas analysis of water column samples," Terrestrial, Atmospheric and Oceanic Sciences, vol. 17, no. 4, pp. 933-950, 2006.

[19] X. Su, F. Chen, S. Wei et al., "Preliminary study on the correlation between microbial abundance and methane concentration in sediments from cold seeps in the northern South China Sea," Geoscience, vol. 21, no. 1, pp. 101-104, 2007 (Chinese).
[20] Y. Y. Huang, E. Suess, N. Y. Wu et al., "Methane and gas hydrate geology of the Northern South China Sea-Sino-German Cooperative," Cruise report SO-177, Geological Publishing House, Bejingm, China, 2008.

[21] X. Han, E. Suess, Y. Huang et al., "Jiulong methane reef: microbial mediation of seep carbonates in the South China Sea," Marine Geology, vol. 249, no. 3-4, pp. 243-256, 2008.

[22] B. Huang, "Gas Potential and its favorable exploration areas in Southeast Hainan Basin,” Natural Gas Industry, vol. 19, no. 1, pp. 34-40, 1999 (Chinese).

[23] J. He, B. Xia, D. Sun et al., "Hydrocarbon accumulation, migration and play targets in the Southeast Hainan Basin, South China Sea," Petroleum Exploration and Development, vol. 33, no. 1, pp. 53-58, 2006 (Chinese).

[24] B. Wu, G. Zhang, Y. Zhu et al., "Progress of gas hydrate investigation in China offshore," Earth Science Frontiers, vol. 10, no. 1, pp. 177-188, 2003 (Chinese).

[25] J. Liu and C. Wang, "Thermal fluid in Ying-Qiong Basin and its significance of oil-gas geology," Natural Gas Exploration and Development, vol. 27, no. 1, pp. 12-15, 2004 (Chinese).

[26] M. Wang, "The character of overpressure and its relationship with the distribution of oil and gas Southeast Hainan Basin," Offshore Oil, vol. 23, no. 1, pp. 15-21, 2003 (Chinese).

[27] J. He, "The evolving of gas hydrate and the exploration foreground in the north of South China Sea," Offshore Oil, vol. 23, no. 1, pp. 57-64, 2003 (Chinese).

[28] D. Chen, X. Li, and B. Xia, "Distribution of gas hydrate stable zones and resource prediction in the Southeast Hainan Basin of the South China Sea," Chinese Journal of Geophysics, vol. 47, pp. 483-489, 2004 (Chinese).

[29] S. Jiang, T. Yang, Z. Xue et al., "Chlorine and sulfate concentrations in pore waters from marine sediments in the north margin of the South China Sea and their implications for gas hydrate exploration," Geoscience, vol. 19, pp. 45-54, 2005 (Chinese).

[30] X. Su, F. Chen, X. Yu et al., "A pilot study on Miocene through Holocene sediments from the continental slope of the South China Sea in correlation with possible distribution of gas hydrates," Geoscience, vol. 19, pp. 1-3, 2005 (Chinese).

[31] H. Jiang, H. Dong, S. Ji, Y. Ye, and N. Wu, "Microbila diversity in the deep marine sediment from the Qiongdongnan Basin in China Sea," Geomicrobiology Journal, vol. 24, no. 6, pp. 505517, 2007.

[32] Y. Van Lith, R. Warthmann, C. Vasconcelos, and J. A. McKenzie, "Microbial fossilization in carbonate sediments: a result of the bacterial surface involvement in dolomite precipitation," Sedimentology, vol. 50, no. 2, pp. 237-245, 2003.

[33] D. T. Wright and D. Wacey, "Precipitation of dolomite using sulphate-reducing bacteria from the Coorong Region, South Australia: significance and implications," Sedimentology, vol. 52, no. 5, pp. 987-1008, 2005.

[34] H. L. Ehrlich, "Microbial formation and degrafation of carbonates," in Geomicrobiology, pp. 183-228, Marcel Dekker, New York, NY, USA, 4th edition, 2002.

[35] S. Cavagna, P. Clari, and L. Martire, "The role of bacteria in the formation of cold seep carbonates: geological evidence from Monferrato (Tertiary, NW Italy)," Sedimentary Geology, vol. 126, no. 1-4, pp. 253-270, 1999.

[36] M. V. S. Guptha, "Authigenic gypsum in a deep sea core from southeastern Arabian sea," Journal of the Geological Society of India, vol. 21, no. 11, pp. 568-571, 1980.

[37] E. Suess, M. E. Torres, G. Bohrmann et al., "Gas hydrate destabilization: enhanced dewatering, benthic material turnover and large methane plumes at the Cascadia convergent margin," 
Earth and Planetary Science Letters, vol. 170, no. 1-2, pp. 1-15, 1999.

[38] J. Wang, E. Suess, and D. Rickert, “Authigenic gypsum found in gas hydrate-associated sediments from Hydrate Ridge, the eastern north Pacific," Scinece in China D, vol. 33, no. 5, pp. 433-441, 2003 (Chinese).

[39] M. E. Torres, H. J. Brumsack, G. Bohrmann, and K. C. Emeis, "Barite fronts in continental margin sediments: a new look at barium remobilization in the zone of sulfate reduction and formation of heavy barites in diagenetic fronts," Chemical Geology, vol. 127, no. 1-3, pp. 125-139, 1996.

[40] J. Greinert, G. Bohrmann, and E. Suess, "Gas hydrate-associated carbonates and methane-venting at Hydrate Ridge: classification, distribution and origin of authigenic lithologies," in Natural Gas Hydrates: Occurrence, Distribution and Detection, C. K. Paull and W. P. Dillon, Eds., vol. 124, pp. 99-113, American Geophysical Union, Washington, DC, USA, 2001.

[41] G. Aloisi, K. Wallmann, S. M. Bollwerk, A. Derkachev, G. Bohrmann, and E. Suess, "The effect of dissolved barium on biogeochemical processes at cold seeps," Geochimica et Cosmochimica Acta, vol. 68, no. 8, pp. 1735-1748, 2004.

[42] M. E. Böttcher and A. Lepland, "Biogeochemistry of sulfur in a sediment core from the west-central Baltic Sea: evidence from stable isotopes and pyrite textures," Journal of Marine Systems, vol. 25, no. 3-4, pp. 299-312, 2000.

[43] R. T. Wilkin and M. A. Arthur, "Variations in pyrite texture, sulfur isotope composition, and iron systematics in the black sea: evidence for late pleistocene to holocene excursions of the $\mathrm{O}_{2}-\mathrm{H}_{2} \mathrm{~S}$ redox transition," Geochimica et Cosmochimica Acta, vol. 65, no. 9, pp. 1399-1416, 2001.

[44] P. Alfonso, R. M. Prol-Ledesma, C. Canet, J. C. Melgarejo, and A. E. Fallick, "Sulfur isotope geochemistry of the submarine hydrothermal coastal vents of Punta Mita, Mexico," Journal of Geochemical Exploration, vol. 78-79, pp. 301-304, 2003.

[45] S. Lin, K. M. Huang, and S. K. Chen, "Organic carbon deposition and its control on iron sulfide formation of the southern East China Sea continental shelf sediments," Continental Shelf Research, vol. 20, no. 4-5, pp. 619-635, 2000.

[46] M. A. A. Schoonen, "Mechanisms of sedimentary pyrite formation," in Sulfur Biogeochemistry: Past and Present, J. P. Amend, K. J. Edwards, and T. W. Lyons, Eds., pp. 117-134, The Geological Society of America, Colo, USA, 2004.

[47] J. Liu, H. Lu, Z. Liao et al., "Distribution in sulfides in shallow sediments in Dongsha area, South China Sea, and its relationship to gas hydrates," Earth Science Froniers, vol. 12, no. 3, pp. 258-262, 2005 (Chinese).

[48] H. Lu, F. Chen, J. Liu et al., "Authigenic mineral associated with sedimentary environment of gas hydrate deposit and their occurrence in South China Sea," Geological Research of South China Sea, vol. 1, pp. 93-104, 2006 (Chinese).

[49] S. J. Mazzullo, "Organogenic dolomitization in peritidal to deep-sea sediments," Journal of Sedimentary Research, vol. 70, no. 1, pp. 10-23, 2000.

[50] J. W. Pohlman, C. Ruppel, D. R. Hutchinson, R. Downer, and R. B. Coffin, "Assessing sulfate reduction and methane cycling in a high salinity pore water system in the northern Gulf of Mexico," Marine and Petroleum Geology, vol. 25, no. 9, pp. 942-951, 2008.

[51] S. Ritger, B. Carson, and E. Suess, "Methane-derived authigenic carbonates formed by subduction- induced pore-water expulsion along the Oregon/Washington margin," Geological Society of America Bulletin, vol. 98, no. 2, pp. 147-156, 1987.
[52] D. S. Stakes, D. Orange, J. B. Paduan, K. A. Salamy, and N. Maher, "Cold-seeps and authigenic carbonate formation in Monterey Bay, California," Marine Geology, vol. 159, no. 1-4, pp. 93-109, 1999.

[53] W. S. Borowski, C. K. Paull, and W. Ussler, "Global and local variations of interstitial sulfate gradients in deep-water, continental margin sediments: sensitivity to underlying methane and gas hydrates," Marine Geology, vol. 159, no. 1-4, pp. 131$154,1999$.

[54] S. P. Hesselbo, D. R. Gröcke, H. C. Jenkyns et al., "Massive dissociation of gas hydrate during a Jurassic oceanic anoxic event," Nature, vol. 406, no. 6794, pp. 392-395, 2000.

[55] C. K. Paull, R. Matsumoto, P. J. Wallace et al., Proceedings of the Ocean Drilling Program, vol. 164, National Science Foundation and Joint Oceanographic Institutions, College Station, Tex, USA, 1996.

[56] S. J. Burns, "Early diagenesis in Amazon Fan sediments," in Proceedings of the Ocean Drilling Program, Scientific Results, R. D. Flood, D. J. W. Piper, A. Klaus et al., Eds., vol. 155, pp. 497504, National Science Foundation and Joint Oceanographic Institutions, College Station, Tex, USA, 1997.

[57] N. M. Rodriguez, C. K. Paull, and W. S. Borowski, “Zonation of authigenic carbonates within gas hydrate-bearing sedimentary sections on the Blake Ridge: offshore southeastern North America," in Proceedings of the Ocean Drilling Program, Scientific Results, C. K. Paull, R. Matsumoto, P. J. Wallace et al., Eds., vol. 164, pp. 301-312, National Science Foundation and Joint Oceanographic Institutions, College Station, Tex, USA, 2000.

[58] F. Inagaki, M. Suzuki, K. Takai et al., "Microbial communities associated with geological horizons in coastal subseafloor sediments from the Sea of Okhotsk," Applied and Environmental Microbiology, vol. 69, no. 12, pp. 7224-7235, 2003. 

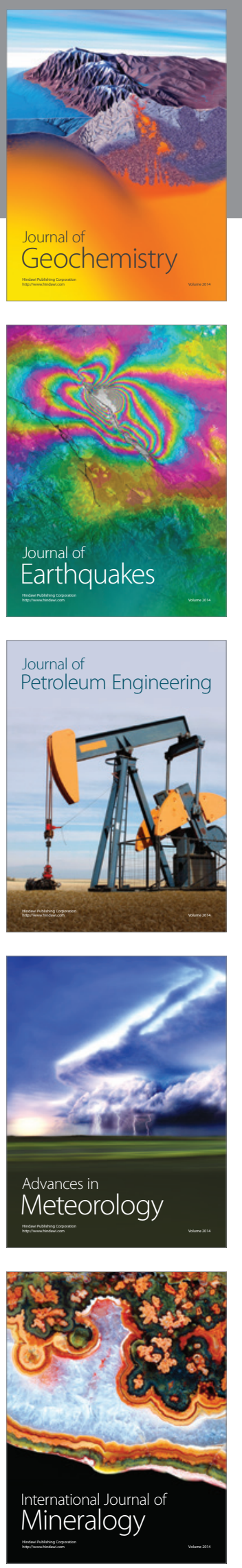
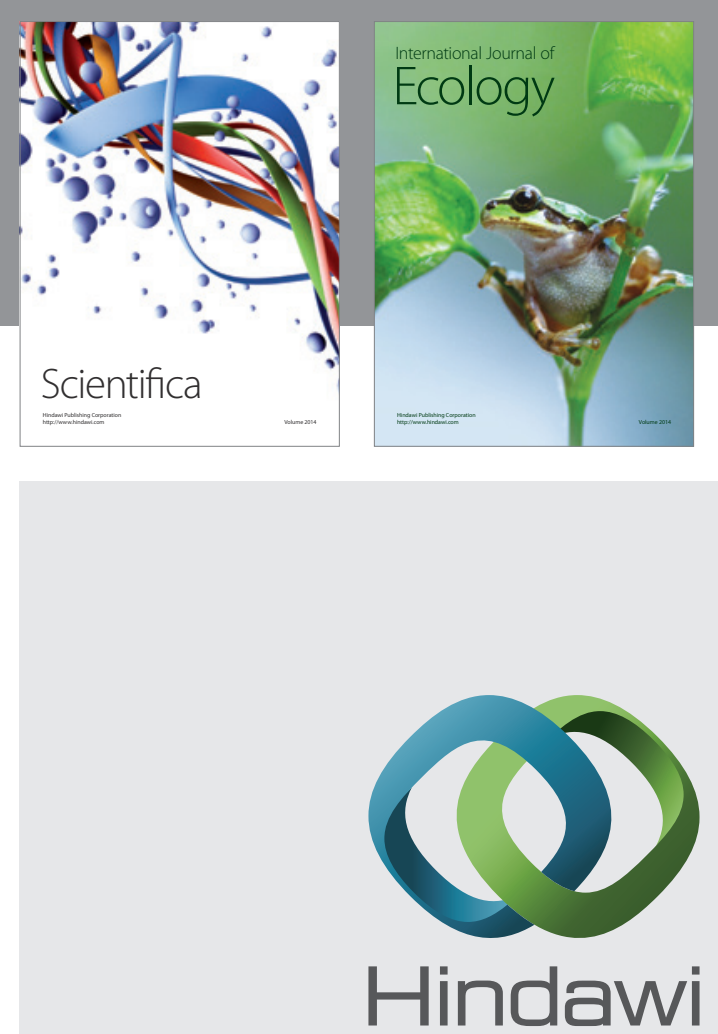

Submit your manuscripts at http://www.hindawi.com
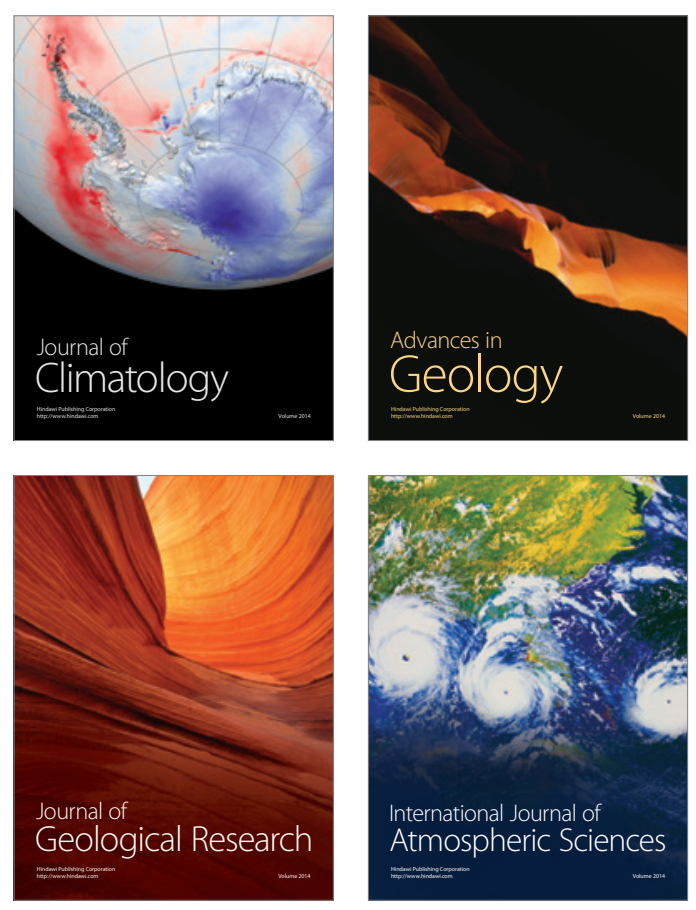
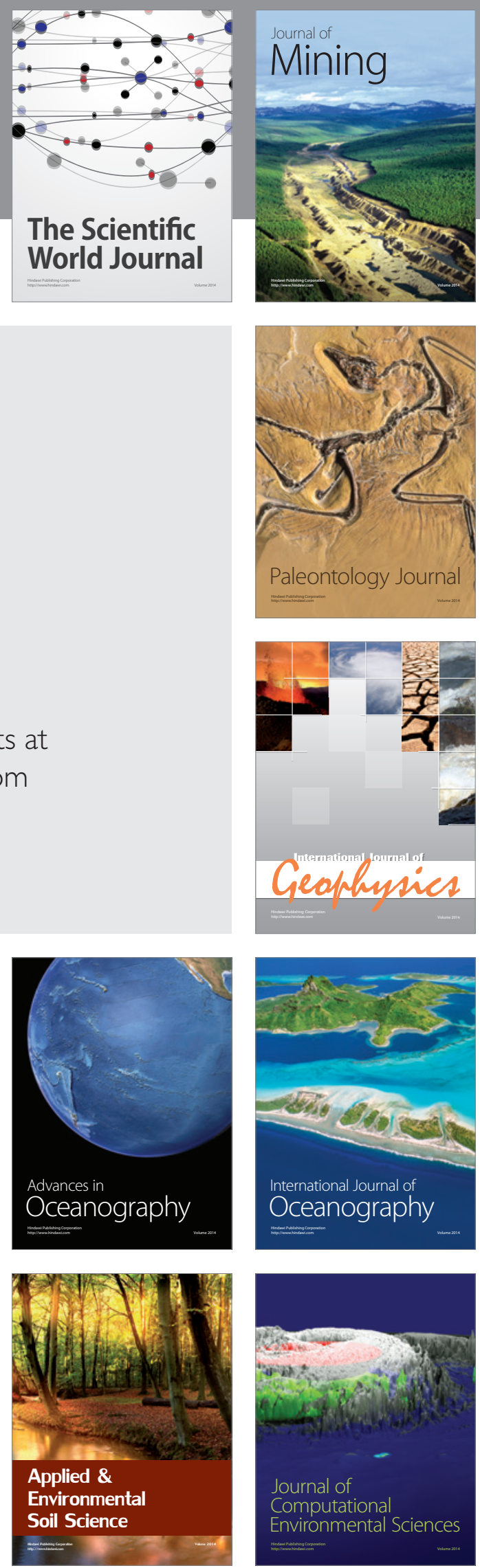